\title{
Kandungan Logam Berat Besi (Fe) Pada Air, Sedimen, Dan Kerang Hijau (Perna viridis) Di Perairan Tanjung Emas Semarang
}

\author{
Endang Supriyantini* dan Hadi Endrawati
}

Jurusan Ilmu Kelautan, Fakultas Perikanan dan Ilmu Kelautan, Universitas Diponegoro JI. Prof. H. Soedharto, SH, Tembalang Semarang. 50275 Telp/Fax (024) 7474698

Email: supri_yantini@yahoo.com

\begin{abstract}
Abstrak
Logam berat Fe merupakan logam berat essensial yang keberadaannya dalam jumlah tertentu sangat dibutuhkan oleh organisme hidup, namun dalam jumlah yang berlebih dapat menimbulkan efek racun.Penelitian ini bertujuan untuk menganalisis kandungan dan tingkat pencemaran logam berat Fe pada air, sedimen, dan kerang hijau (Perna viridis) di perairan Tanjung Emas Semarang. Penelitian ini dilaksanakan pada tanggal 7 November dan 7 Desember 2013 dengan metode penelitian deskriptif. Logam berat Fe dalam sampel air, sedimen dan kerang hijau dianalisis di Laboratorium Balai Besar Teknologi Pencegahan Pencemaran Industri (BTPPI) Semarang dengan menggunakan metode AAS (AtomicAbsorption Spectrophotometry). Hasil penelitian menunjukkan bahwa perairan Tanjung Emas masih dalam taraf terkontaminasi logam Fe. Sedangkan pada sedimen dan pada kerang hijau (Perna viridis) sudah terindikasi tercemar logam Fe.Meskipun demikian variasi faktor lingkungan seperti suhu, salinitas, $\mathrm{pH}$, kecepatan arus dan jenis sedimen juga memberikan kontribusi yang cukup penting terhadap kandungan logam $\mathrm{Fe}$.
\end{abstract}

Kata Kunci: logam Fe, Air, Sedimen, Perna viridis, metode AAS

\begin{abstract}
Heavy metalsiron $(\mathrm{Fe})$ is anessentialheavy metalswhose presencein a certain amountis neededby living organisms, but inexcessiveamountscan causetoxic effects. The aims of the research is to analyze the heavy metals coccentration and the pollution level of Fe in water, sediment, and green mussels (Perna viridis) at Tanjung Emas Semarang. This research was conducted from 7 November and 7 December 2013 using the Atomic Absorption Spectrophotometry (AAS) and research methodswithdescriptive. The results showed that the waters of the Tanjung Emas is still in the stage of heavy metals contaminated iron (Fe). Sediment and green mussels (Perna viridis)already indicated heavy metal contaminatediron. However, variations inenvironmental factorssuch astemperature, salinity, $\mathrm{pH}$, flow velocity an dsediment types also providean important contributionto heavy metal contentof iron( $\mathrm{Fe})$.
\end{abstract}

Key Words: Fe, water, sediment, Perna viridis, metode AAS

\section{PENDAHULUAN}

Tanjung Emas merupakan pelabuhan utama yang ada di Jawa Tengah yang mempunyai peranan penting bagi perkembangan masyarakat di wilayah Jawa Tengah.Pelabuhan Tanjung Emas merupakan sarana perdagangan dan
bisnis.Setiap hari perahu dan kapal-kapal merapat untuk keperluan perikanan, bongkar muat, menaik turunkan penumpang serta kegiatan lainnya. Beberapa pabrik/industri yang ada di sekitar Tanjung Emas seperti PLTGU, industri garmen, industri pengolahan tepung, industri pembuatan mesin otomatis, 
pengelasan kapal, kegiatan budidaya, kegiatan rumah tangga dan beberapa kegiatan lainnya.Pesatnya perkembangan industri seringkali diikuti dengan meningkatnya polutan dari berbagai sumber. Diduga kegiatan-kegiatan industri yang ada disekitar perairan Tanjung Emas tersebut akan menyumbangkan limbah yang banyak mengandung logam berat, salah satunya yaitu logam Fe. Sebagian besar logam seperti $\mathrm{Fe}, \mathrm{Pb}, \mathrm{Zn}, \mathrm{Al} \& \mathrm{CU}$ mudah terlarut dan sangat mobil pada $\mathrm{pH}$ $<5$ (Stumn \& Morgan, 1996). Pada pH 6,5-7 adalah merupakan $\mathrm{pH}$ yang ideal. Unsurunsur hara akan relative banyak tersedia pada $\mathrm{pH}$ tersebut. Sedangkan pada $\mathrm{pH}$ rendah unsur-unsur seperti $\mathrm{Al}, \mathrm{Mn} \& \mathrm{Fe}$ akan bersifat racun. Kadar besi $(\mathrm{Fe})>1 \mathrm{mg} / \mathrm{L}$ dianggap membahayakan kehidupan organisme akuatik (Moore, 1991).

Buangan industri yang mengandung persenyawaan logam berat $\mathrm{Fe}$ bukan hanya bersifat toksik terhadap tumbuhan tetapi juga terhadap hewan dan manusia. Hal ini berkaitan dengan sifat-sifat logam berat yang sulit didegradasi, sehingga mudah terakumulasi dalam lingkungan perairan dan keberadaannya secara alami sulit dihilangkan, dapat terakumulasi dalam biota perairan termasuk kerang, ikan dan sedimen, memiliki waktu paruh yang tinggi dalam tubuh biota laut serta memiliki nilai factor konsentrasi yang besar dalam tubuh organisme.

Logam $\mathrm{Fe}$ merupakan logam essensial yang keberadaannya dalam jumlah tertentu sangat dibutuhkan oleh organisme hidup, namun dalam jumlah berlebih dapat menimbulkan efek racun. Tingginya kandungan logam $\mathrm{Fe}$ akan berdampak terhadap kesehatan manusia diantaranya bisa menyebabkan keracunan (muntah), kerusakan usus, penuaan dini hingga kematian mendadak, radang sendi, cacat lahir, gusi berdarah, kanker, sirosis ginjal, sembelit, diabetes, diare, pusing, mudah lelah, hepatitis, hipertensi, insomnia (Parulian, 2009).

Berdasarkan hasil pengamatan wilayah perairan Tanjung Emas banyak ditemukan kerang hijau (Pernaviridis). Penduduk sekitar banyak memanfaat- kannya untuk dikonsumsi dan sebagian dijual ke konsumen. Mengingat hal tersebut, maka perlu dilakukan penelitian untuk mengetahui sejauh mana kontaminasi logam Fe dalam tubuh kerang, mengingat kerang merupakan indicator yang baik dalam memonitor suatu pencemaran lingkungan disebabkan oleh sifatnya yang menetap dalam suatu habitat tertentu dan cara makannya yang filter feeder. Selain itu juga perlu dilakukan penelitian terhadap kandungan logam Fe dalam air dan sedimen.

\section{MATERI DAN METODE}

Sampel air, sedimen dan kerang hijau (Perna viridis) diambil dari tiga stasiun di sekitar perairan Tanjung Emas Semarang (Gambar 1). Penelitian ini dilaksanakan pada tanggal 7 November dan 7 Desember 2013 dengan metode analisisdeskriptif. Kandungann logam berat Fe dalam sampel air, sedimen dan kerang hijau dianalisis di Laboratorium Balai Besar Teknologi Pencegahan Pencemaran Industri (BTPPI) Semarang dengan menggunakan metode AAS (Atomic Absorption Spectrophotometry). Analisis kandungan logam berat $\mathrm{Fe}$ untuk sampel air dilakukan dengan mengambil $250 \mathrm{ml}$ sampel air laut kedalam corong pemisah polyetilen yang sudah disaring dengan menggunakan kertas saring berukaran 0,45 $\mu \mathrm{m}$ dengan menambahkan amonium pirolidin ditiokarbonat (APDC) dan metil isobutil keton (MIBK) sampai fase organik dan fase air terpisah. Fase organik digunakan untuk membuat larutan standar dan kemudian ditambahkan $\mathrm{HNO}_{3}$ pekat dan air suling bebas ion sampai kedua fase terpisah. Fase air ditampung untuk diaspirasikan pada AAS. Perhitungan kandungan logam $\mathrm{Fe}$ pada air menggunakan rumus (BTPPI, 2013), sebagai berikut :

Kadar logam Fe $(\mathrm{mg} / L)=$ hasil pengukuran AAS $\times \frac{\text { Faktor pemekatan }(m L)}{\text { Vol awal contoh }(m L)}$

Analisis kandungan logam berat $\mathrm{Fe}$ dalam sedimen dilakukan dengan memasukkan contoh sedimen ke dalam oven selama 3 jam lalu ditumbuk sampai 
halus, sebanyak 2 gram sampel dimasukkan kedalam labu, didihkan \& ditambahkan dengan $\mathrm{HNO}_{3}$ untuk didestruksi selama 3 jam kemudian disaring dan filtratmya diencerkan dan siap untuk diaspirasikan. Perhitungan kandungan logam Fe pada sedimen menggunakan rumus (BTPPI, 2013), sebagai berikut:

$\operatorname{Kadar} \operatorname{logam} \mathrm{Fe}(\mathrm{mg} / \mathrm{kg})=\frac{\text { hasil pengukuran } A A S\left(\frac{\mathrm{mg}}{\mathrm{L}}\right)}{\text { berat contoh }(\mathrm{gr})} \times \frac{100}{\operatorname{Kadar} \text { padat }(\%)}$

Adapun untuk sampel kerang, terlebih dahulu diambil sampel dagingnya. Sampel daging tersebut kemudian dipanaskan kedalam hot plate sampai berbentuk arang, kemudian diabukan dalam tanur dan ditambahkan $\mathrm{HNO}_{3}$ dan aquades. Sampel kemudian disaring dan siap untuk diaspirasikan pada AAS. Perhitungan kandungan logam Fe pada kerang menggunakan rumus (BTPPI, 2013), sebagai berikut :

$\operatorname{Kadar~logam~Fe~}(\mathrm{mg} / \mathrm{kg})=\frac{\text { hasil pengukuran AAS }\left(\frac{\mathrm{mg}}{\mathrm{L}}\right) \times \operatorname{Vol} \text { akhir }(\mathrm{mL})}{\text { berat contoh }(\mathrm{gr})}$

Dilakukan pula pengukuran panjang, lebar, dan tebal cangkang kerang dengan menggunakan jangka sorong untuk mengetahui kisaran panjang cangkang yang berada disekitar stasiun
penelitian.Analisis ukuran butir sedimen juga dilakukan untuk menentukan pembagian butiran (gradasi) dengan menggunakan saringan berukuran 0,074 $\mathrm{mm}$. Pengukuran parameter kualitas perairan dilakukan selama penelitian untuk mengetahui kondisi perairan di lokasi penelitian.

\section{HASIL DAN PEMBAHASAN}

Berdasarkan hasil penelitian di perairan Tanjung Emas Semarang di tiga titik stasiun yang berbeda, diketahui bahwa kandungan logam Fedalam kolom air baik pada bulan November maupun Desember 2013 menunjukkan hasil yang bervariasi yakni antara $0,031-0,371 \mathrm{mg} / \mathrm{L}$ (November) dan 0,105-0,234 mg/L (Desember) dan pada pengamatan selama dua bulan tersebut kandungan logam $\mathrm{Fe}$ tertinggi semuanya terdapat pada muara (stasiun 1)dan terendah di pelabuhan (stasiun 3). Rata-rata kandungan logam Fe pada sedimen (November) tertinggi terdapat padamuara (stasiun 1) yaitu $27,945 \mathrm{mg} / \mathrm{kg}$ dan terendah di tambak (stasiun 2) yaitu $19,681 \mathrm{mg} / \mathrm{kg}$. Sedangkan pada bulan Desember logam $\mathrm{Fe}$ pada sedimen tertinggi di pelabuhan (stasiun 3) yaitu $34,051 \mathrm{mg} / \mathrm{kg}$ dan terendah di muara
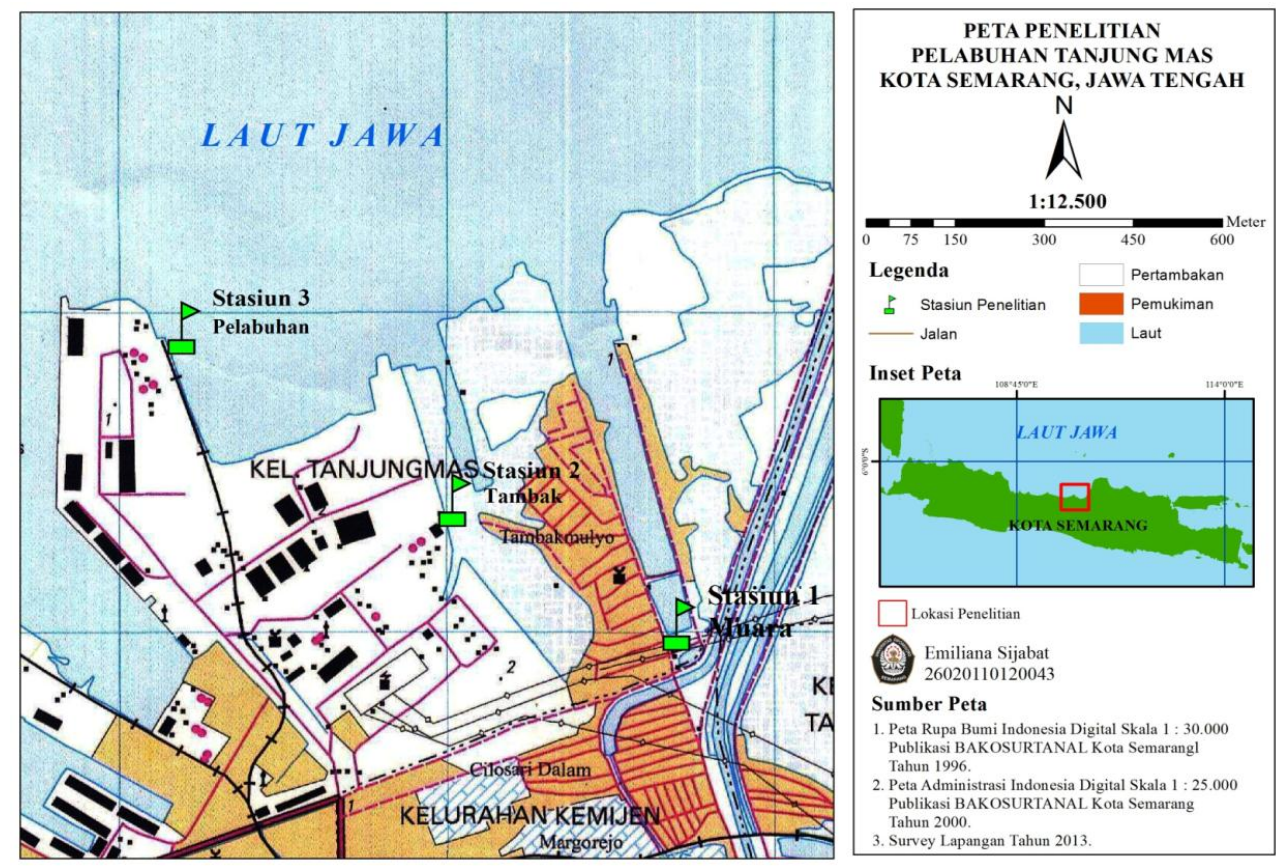

Gambar 1.Peta Lokasi Penelitian Logam Berat Fe di Perairan Tanjung Emas Semarang 

(stasiun 1) yaitu $26,727 \mathrm{mg} / \mathrm{kg}$. Rata-rata kandungan logam berat $\mathrm{Fe}$ pada kerang hijau ( $P$. viridis) pada sampling bulan November tertinggi terdapat padamuara (stasiun 1) sebesar 203,596 $\mathrm{mg} / \mathrm{kg}$ dan terendah di tambak (stasiun 2) 161,430 $\mathrm{mg} / \mathrm{kg}$. Sedangkan pada bulan Desember kandungan logam Fe pada kerang hijau tertinggi terdapat pada muara yaitu 95,963 $\mathrm{mg} / \mathrm{kg}$ dan terendah di tambak yaitu $84,866 \mathrm{mg} / \mathrm{kg}$ (Tabel 1 ).

Kandungan logam berat $\mathrm{Fe}$ dalam kolom air dari ke tiga stasiun tersebut masih menunjukkan dibawah baku mutu air laut. Hal ini disebabkan karena logam berat yang masuk ke dalam lingkungan perairan akan mengalami pengenceran akibat pengaruh pasang surut, adsorbsi dan absorbsi oleh organisme perairan (Bryan, 1976). Namun demikian jika diperhatikan dari ketiga stasiun tersebut, di daerah muara mempunyai kandungan logam berat $\mathrm{Fe}$ lebih tinggi dibandingkan dengan lokasi lainnya.Tingginya kandunganlogam besi ( $\mathrm{Fe}$ ) di muara diduga disebabkan oleh kandungan Fe yang berasal dari beberapa sumber, yaitu selain dari tanah juga berasal dariaktivitas manusia yang terjadi di daratan yakniadanya buangan limbah rumah tangga yang mengandung besi, reservoir air dari besi, endapan-endapan buangan industri dan korosi dari pipa-pipa air yang mengandung logam besi yang dibawa aliran sungai menuju ke muara. Hal ini dapat juga dikaitkan dengan kondisi perairan pada saat penelitian, berdasarkan hasil pengukuran kualitas perairan terhadap kandungan oksigen terlarut (DO) di muara menunjukkan hasil paling rendah jika dibandingkan dengan daerah pelabuhan dan tambak yaitu sekitar 1,68-1,87 mg/L. Ini mengindikasikan bahwa di muara telah terjadi pencemaran limbah yang lebih berat yang mengandung salah satunya logam Fe.

Menurut Begum et al. (2009a) dikatakan bahwa pencemaran berat apabila kadar DO antara 0,1-2 $\mathrm{mg} / \mathrm{L}$ , Rendahnya Oksigen terlarut ini diduga dipakai oleh bakteri untuk menguraikan zat pencemar tersebut agar bahan buangan yang ada dalam air dapat teroksidasi melalui reaksi kimia, sehingga akan berdampak pada penurunan kadar oksigen terlarut.

Dari hasil analisis, terlihat bahwa seluruh kandungan logam berat besi (Fe) pada sedimen di semua stasiun jauh lebih besar dibandingkan logam berat Fe yang ada di kolom air.Hal ini diduga dipengaruhi oleh kondisi $\mathrm{pH}$, temperature dan DO dalam air.

Hasil pengukuran $\mathrm{pH}$ selama penelitian diperoleh $\mathrm{pH}$ air cenderung rendah (asam) yaitu antara 5,39-7,02. $\mathrm{pH}$ air berpengaruh terhadap kesadahan kadar besi dalam air, apabila $\mathrm{pH}$ air rendah akan berakibat terjadinya proses korosif sehingga menyebabkan larutnya besi dan logam lain dalam air. Menurut Begum et al. (2009 a), $\mathrm{pH}<7$ dapat melarutkan logam. Dalam keadaan $\mathrm{pH}$ rendah besi yang ada dalam air berbentuk ferro $\left(\mathrm{Fe}^{2+}\right.$ ) dan ferri $\left(\mathrm{Fe}^{3+}\right)$, dimana bentuk ferri akan mengendap dan tidak larut dalam air serta tidak dapat dilihat dengan mata sehingga mengakibatkan air menjadi berwarna, berbau dan berasa. Hal ini juga didukung oleh kecepatan arus yang sangat rendah. Hasil pengukuran memperlihatkan bahwa kecepatan arus dilokasi penelitian berdasarkan dua bulan pengamatan (November \& Desember) yaitu berkisar antara 0,02-0,13 m/detik. Kecepatan arus yang rendah, mendukung kation ferri $\left(\mathrm{Fe}{ }^{3+}\right.$ ) semakin mudah terdeposit dalam sedimen terutama pada clay dan silt (Johnson et al., 2005).

Selain itu temperature air juga akan mendukung tingginya kelarutan besi dalam air. Hasil pengukuran di lapangan tercatat temperature sekitar $29,77-32,35^{\circ} \mathrm{C}$. hasil ini melebihi baku mutu yang telah ditentukan yaitu $28-30^{\circ} \mathrm{C}$ (Kepmen LH No.51, 2004). Temperatur yang tinggi menyebabkan menurunnya kadar oksigen terlarut (DO) dalam air. Kenaikan temperature air dapat menguraikan derajat kelarutan mineral sehingga kelarutan $\mathrm{Fe}$ pada air tinggi.Kelarutan logam berat juga dipengaruhi oleh kondisi DO diperairan.Menurut Rozak dan Rochyatun (2007), konsentrasi DO yang rendah menyebabkan kelarutan logam berat rendah sehingga mudah mengendap ke 
Tabel 1. Hasil Analisis Rata-Rata Kandungan Logam Berat Fe pada Sampel Air, Sedimen, dan Kerang Hijau (Perna viridis) di Perairan Tanjung Emas, Semarang

\begin{tabular}{|c|c|c|c|c|c|c|}
\hline \multirow{3}{*}{ Lokasi } & \multicolumn{6}{|c|}{ Logam Berat Fe } \\
\hline & \multicolumn{3}{|c|}{ November } & \multicolumn{3}{|c|}{ Desember } \\
\hline & $\begin{array}{c}\text { Air } \\
(\mathrm{mg} / \mathrm{l})\end{array}$ & $\begin{array}{c}\text { Sedimen } \\
(\mathrm{mg} / \mathrm{kg})\end{array}$ & $\begin{array}{l}\text { Kerang } \\
(\mathrm{mg} / \mathrm{kg})\end{array}$ & $\begin{array}{c}\text { Air } \\
(\mathrm{mg} / \mathrm{l})\end{array}$ & $\begin{array}{l}\text { Sedimen } \\
(\mathrm{mg} / \mathrm{kg})\end{array}$ & $\begin{array}{l}\text { Kerang } \\
(\mathrm{mg} / \mathrm{kg})\end{array}$ \\
\hline \multicolumn{7}{|l|}{ Stasiun 1} \\
\hline Muara & 0,146 & 22,675 & 193,620 & 0,101 & 32,052 & 65,590 \\
\hline \multirow[t]{2}{*}{ Sungai } & 0,480 & 33,880 & 234,120 & 0,353 & 21,761 & 122,100 \\
\hline & 0,489 & 27,280 & 183,050 & 0,248 & 26,368 & 100,200 \\
\hline Rata-rata & 0,371 & 27,945 & 03,596 & 0,234 & 26,727 & 95,963 \\
\hline \multicolumn{7}{|l|}{ Stasiun 2} \\
\hline \multirow[t]{3}{*}{ Tambak } & 0,118 & 14,872 & 150,680 & 0,067 & 28,147 & 84,410 \\
\hline & 0,103 & 22,926 & 203,370 & 0,232 & 31,212 & 73,560 \\
\hline & 0,422 & 21,247 & 130,240 & 0,272 & 25,629 & 96,630 \\
\hline Rata-rata & 0,214 & 19,681 & 161,430 & 0,190 & 28,329 & 84,866 \\
\hline \multicolumn{7}{|l|}{ Stasiun 3: } \\
\hline \multirow{3}{*}{ Pelabuhan } & 0,051 & 42,143 & - & 0,064 & 45,515 & - \\
\hline & 0,010 & 15,045 & - & 0,082 & 32,131 & - \\
\hline & 0,033 & 25,555 & - & 0,170 & 24,509 & - \\
\hline Rata-rata & 0,031 & 27,581 & - & 0,105 & 34,051 & - \\
\hline Baku Mutu & 0,5 a) & 20 b) & 1 c) & 0,5 a) & 20 b) & $1 \mathrm{cl}$ \\
\hline \multicolumn{7}{|c|}{$\begin{array}{l}\text { Keterangan: } \\
\text { a) USEPA.(1986). Quality Criteria for Water. EPA-440/5-86-001, Office of Water Regulation Standards, } \\
\text { Washington DC, USA } \\
\text { b) Baku mutu sedimen dengan standar sediment quality guideline values for metals and associated } \\
\text { levels of concern to be used in doing assessments of sediment quality.(2003) } \\
\text { c) Badan Standarisasi Nasional (BSN).(2009). Standar Nasional Indonesia (SNI) No. } 7387 \text { Tentang Batas } \\
\text { Maksimal Cemaran Logam Berat dalam Pangan, Jakarta. } \\
\text {-) Tidak ditemukan Kerang Hijau (Perna viridis) }\end{array}$} \\
\hline
\end{tabular}

Tabel 2. Hasil Analisis Ukuran Butir Sedimen di Perairan Tanjung Emas Semarang

\begin{tabular}{lccccl}
\hline \multirow{2}{*}{ Stasiun } & \multicolumn{5}{c}{ Presentase (\%) } \\
\cline { 2 - 6 } & Gravel & Sand & Silt & Clay & \\
\hline 1: Muara Sungai & 0 & 80,90 & 19,10 & 0 & pasir berlumpur \\
2: Tambak & 0 & 12,30 & 70,27 & 17,43 & lumpur berlempung \\
3: Pelabuhan & 0 & 3,60 & 55,54 & 40,86 & lumpur berlempung \\
\hline
\end{tabular}

dasar sedimen. Diketahui bahwa DO di perairan Tanjung Emas sekitar 1,68-7,56 $\mathrm{mg} / \mathrm{L}$.

Kandungan logam berat Fepada sedimen disemua stasiun diketahui lebih tinggi dibandingkan sampel air. Hal ini disebabkan karena adanya proses sedimentasi yang dialami oleh logam berat Fe. Sesuai dengan hasil penelitian Mance (1987) yang menyatakan bahwa kandungan logam berat di sedimen jauh lebih tinggi jika dibandingkan dengan yang ada pada kolom perairan, disebabkan karena logam berat yang masuk kedalam kolom perairan akan diserap oleh partikelpartikel tersuspensi.Sesuai dengan pendapat Boehm (1987), pada sedimen terdapat hubungan antara ukuran partikel sedimen dengan kandungan bahan organik. Pada sedimen yang halus, presentase bahan organik lebih tinggi dari pada sedimen yang kasar. Hal ini berhubungan dengan kondisi lingkungan 
yang tenang, sehingga memungkinkan pengendapan sedimen lumpur yang diikutioleh akumulasi bahan organik ke dasar perairan. Sedangkan pada sedimen yang kasar, kandungan bahan organiknya lebih rendah karena partikel yang lebih halus tidak mengendap. Demikian pula dengan bahan pencemar, kandungan bahan pencemar yang tinggi biasanya terdapat pada partikel sedimen yang halus.Ukuran dan jenis butir sedimen di perairan Tanjung Emas disajikan pada Tabel 2.

Kandungan logam berat Fe dalam kerang memiliki kandungan yang lebih tinggi bila dibandingkan dengan kandungan logam berat $\mathrm{Fe}$ pada kolom perairan dan sedimen. Hal ini diduga karena kerang hijau ( $P$. viridis) memiliki cara makan filter feeder yaitu menyerap makanan dengan menyaring sedimen masuk kedalam tubuhnya, sehingga logam berat $\mathrm{Fe}$ yang terdapat pada sedimen masuk kedalam tubuh kerang hijau ( $P$. viridis) secara terus menerus dan logam berat $\mathrm{Fe}$ terakumulasi dalam tubuhnya. Sesuai dengan pendapat Ward et al.(1986), bahwa logam yang ada dalam tubuh biota sejalan dengan konsentrasi logam di lingkungannya.Darmono (2001) mengatakan bahwa perbedaan kerang dengan organisme lainnya adalah, jenis kerang mampu mengakumulasi logam lebih besar daripada hewan air lainnya karena sifatnya yang menetap, lambat untuk dapat menghindari diri dari pengaruh polusi, dan mempunyai toleransi yang tinggi terhadap konsentrasi logam berat.

Kandungan logam berat yang ada pada kerang juga dipengaruhi oleh kondisi perairan.Berdasarkan hasil pengukuran parameter kualitas perairan Tanjung Emas (Tabel 3), nilai suhu mengalami kenaikan pada stasiun 2 (Tambak) dan stasiun 3 (Pelabuhan) baik pada sampling pertama (November 2013) maupun pada sampling kedua (Desember 2013). Semakin tinggi suhu, maka tingkat akumulasi logam berat dalam sedimen akansemakin tinggi. Menurut Hutagalung (1984)bahwa kenaikan suhu akan menyebabkan tingkat bioakumulasi akan semaki tinggi. Diperkuat
Oleh pendapat Darmono (2001) bahwa semakin tinggi suhu air pada suatu perairan, daya toksisitas semakin meningkat, sehinggakandungan logam berat $\mathrm{Fe}$ lebih mudah diabsorbsi oleh kerang hijau (P. viridis) sehingga kandungan logam berat $\mathrm{Fe}$ dalam tubuhnya meningkat, dan sebaliknya semakin rendah suhu air maka daya toksisitasnya semakin menurun.Naiknya suhu pada perairan akan mempercepat reaksi dalam pembentukan ion-ion logam berat. Menurut Kastoro (1988), suhu normal agar jenis kerang-kerangan daerah tropis dapat hidup adalah 20-35 ${ }^{\circ} \mathrm{C}$, dengan fluktuasi tidak lebih dari $5{ }^{\circ} \mathrm{C}$. Hal ini menunjukkan bahwa kisaran suhu di Perairan Tanjung Emas Semarang masih baik untuk pertumbuhan hidup kerang hijau (P. Viridis).

Berdasarkan hasil pengukuran cangkang, kisaranukuran panjang cangkang kerang hijau (P. viridis) yang ditemukan pada stasiun 2 (Tambak) lebih panjang dibandingkan stasiun 1 (Muara) yaitu berkisar antara2,57-8,4 cm kandungan logam berat Fe antara 84,866$161,430 \mathrm{mg} / \mathrm{kg}$. Sedangkan ukuranpanjang cangkang pada stasiun 1 (Muara) berkisar antara 1,75-6,68 cm dengankandungan logam berat 95,963-203,596 mg/kg. Salah satu yang mempengaruhi akumulasi logam berat pada jaringan organisme laut termasuk kerang adalah ukuran dan fase hidupnya. Hal ini sesuai dengan pendapat Connel dan Miller (1995) bahwa umur dan ukuran tubuh mempengaruhi akumulasi logam berat pada organisme. Menurut Johnson et al. (2005), logam Fe merupakan logam berat essensial yang fungsinya dalam enzim terrodoksin, suksinat dehydrogenase, perokdase, katalase, aldehid oksidase dan sitokrom.

Diduga kerang yang mempunyai ukuran cangkang lebih pendek membutuhkan logam essensial Fe lebih banyak untuk mendukung pertumbuhannya.Namun jika dilihat hasilnya kerang yang diperoleh di Tanjung Emas hampir semuanya mempunyai kandungan $\mathrm{Fe}$ lebih tinggi bahkan melampaui baku mutu yang ditentukan menurut BSN (2009). Oleh karena itu kerang 
Tabel 3. Hasil Rata-Rata Pengukuran Parameter Fisika-Kimia pada Setiap Stasiun di Perairan Tanjung Emas Semarang Periode November-Desember 2013

\begin{tabular}{cccccccc}
\hline \multirow{2}{*}{ Parameter } & \multicolumn{2}{c}{$\begin{array}{c}\text { Stasiun 1 } \\
\text { (Muara sungai) }\end{array}$} & \multicolumn{2}{c}{$\begin{array}{c}\text { Stasiun 2 } \\
\text { (Tambak) }\end{array}$} & \multicolumn{2}{c}{$\begin{array}{c}\text { Stasiun 3 } \\
\text { (Pelabuhan) }\end{array}$} & \multirow{2}{*}{ BM $^{*}$} \\
\cline { 2 - 7 } & Nov & Des & Nov & Des & Nov & Des & \\
\hline pH & 6,81 & 5,90 & 7,02 & 5,39 & 6,79 & 5,85 & $6,5-8,5$ \\
Salinitas (\%) & 21,67 & 19,33 & 31,67 & 31,33 & 32 & 33,23 & 35 \\
Temperatur ( $\left.{ }^{\circ} \mathrm{C}\right)$ & 29,77 & 30,4 & 30,67 & 32 & 31,46 & 32,35 & $28-30$ \\
DO $(\mathrm{mg} / \mathrm{L})$ & 1,68 & 1,87 & 5,67 & 4,25 & 7,48 & 7,56 & $>5$ \\
Arus (m/detik) & 0,13 & 0,10 & 0,02 & 0,02 & 0,05 & 0,05 & - \\
Kedalaman (m) & 0,68 & 0,86 & 1,41 & 1,27 & 3,86 & 2,89 & - \\
Kecerahan (m) & 0,39 & 0,18 & 0,55 & 0,37 & 1,02 & 0,89 & $>3$ \\
Kondisi Cuaca & Cerah & Berawan & Cerah & Berawan & Cerah & Cerah & \\
\hline
\end{tabular}

Keterangan:

* Baku Mutu menurut Keputusan Menteri Negara Lingkungan Hidup No 51 Tahun 2004 yang ada di Tanjung Emas sudah tercemar logam berat besi (Fe).

Kandungan $\mathrm{Fe}$ di lokasi perairan Tanjung Emas Semarang selama penelitian menunjukkan bahwa diperairantersebut masih dalam taraf terkontaminasi logam Fe karena masih berada dibawah baku mutu yang telah ditetapkan oleh USEPA (1986), tentang baku mutu air laut.Sedangkan, kandungan logam berat $\mathrm{Fe}$ dalam sedimen dari seluruh titik lokasi penelitian hampir semua melebihi baku mutu yang telah ditetapkan oleh Wisconsin Department of Natural Resources tahun 2003, dimana baku mutu untuk kandungan logam Fe pada sedimen yaitu sebesar 20 $\mathrm{mg} / \mathrm{kg}$.Kandungan logam berat Fe pada kerang hijau dari seluruh titik lokasi penelitian baik pada bulan November maupun Desember berkisar antara 84,866$203,596 \mathrm{mg} / \mathrm{kg}$, dan hasil ini sudah melewati baku mutu yang telah ditetapkan oleh Badan Standarisasi Nasional tahun 2009, dimana baku mutu logam Fe pada bivalvia sebesar $1,0 \mathrm{mg} / \mathrm{kg}$.

\section{KESIMPULAN}

Kandungan Logam Fe pada air di Perairan Tanjung Emas Semarang belum tercemar logam Fe karena masih dibawah baku mutu yaitu berkisar 0,031-0,371 mg/L (November 2013) dan 0,105-0,234 mg/L (Desember 2013). Sedimen yang ada di Perairan Tanjung Emas Semarang sudah terindikasi tercemar logam berat $\mathrm{Fe}$ yaitu berkisar antara 19,681-27,945 $\mathrm{mg} / \mathrm{kg}$
(November 2013) dan 26,727-34,051 mg/kg (Desember 2013).Sementara kandungan logam berat Fe dalam kerang hijau ( $P$. viridis) pada bulan November 2013lebih tinggi dibandingkan bulan Desember 2013 dan sudah melampaui batas ambang yang ditentukan yaitu 161,430-203,596 $\mathrm{mg} / \mathrm{kg}$ (November) dan 84,866-95,963 $\mathrm{mg} / \mathrm{kg}$ (Desember).

\section{UCAPAN TERIMAKASIH}

Ucapan terima kasih disampaikan kepada reviewer yang turut membantu dalam memperbaiki naskah ini dan terimakasih disampaikan pula kepada Herdis Syariefudin dan Emil Sijabat yang telah membantu pelaksanaan penelitian hingga selesai

\section{DAFTAR PUSTAKA}

Begum, A., Krishna, H., Irfanulla, K., 2009a, Analysis of Heavy Metals in Water, Sediments and Fish Samples of Madivala Lakes of Bangalore, Karnataka. International Journal of ChemTechResearch, Vol.1, No.2, pp. 245-249.

Boehm, P. D. 1987. Transport and transformation process regarding hydrocarbon and metal pollution in offshore sedimenary environment in: Long term effect of shore oil and gas 
development. D. F. Boesch and N. N. Rabalai. Elsivier applied science. London.

Bryan, G.W. 1976. Heavy Metal Contamination in The Sea. In: Jonhston R (ed). Marine Pollution. Academic Press, London.

Connel, D.W. dan G. J. Miller. 1995. Kimia dan Ekotoksikologi Pencemaran. (terjamahan: Yanti Kastoer). UI-Press. Jakarta. $520 \mathrm{hlm}$

Darmono, 2001. Lingkungan Hidup dan Pencemaran. Universitas Indonesia, Jakarta.

Hutagalung, H.P. 1984. Logam Berat dalam Lingkungan Laut. Oseanologi Vol IX No:LP3O-LIPI, Jakarta

Johnson, V., Peterson, R., Olsen, K., 2005, Heavy Metal Transport and Behavior In The Lower ColumbiaRiver, USA, Environmental Monitoring and Assessment (Springer), Vol. 110, pp. 271-289

Kastoro, W. 1988. Beberapa Aspek Biologi Kerang Hijau (Perna viridis) dari Perairan Binaria, Ancol Teluk Jakarta. Jurnal Pen. Perikanan Laut. No 45: 830 $-102$.

Kepmen LH. 2004. Keputusan Menteri Negara Lingkungan Hidup No. 51 Tahun 2004 tentang Baku Mutu Air
Laut. Deputi Menteri Lingkungan Hidup, Bidang Kebijakan dan Kelembagaan L. H, Jakarta, $11 \mathrm{hlm}$.

Mance, G. 1987. Pollution Trreat of Heavy Metals in Aquatic Environmens. Page Bross Limited. Great Britain.

Moore, J.W. 1991. Inorganic Contaminant of Surface Water Springer Verlag, New York.

Parulian, A. 2009. Monitoring dan Analisis Kadar Aluminium (Al) dan Besi (Fe) Pada Pengolahan Air Minum PDAM Tirtanadi Sunggal. Medan : Pascasarjana Universitas Sumatera Utara (USU).

Rozak, A., dan Rochyatun, E. 2007. Pemantauan Kadar Logam Berat dalam Sedimen di Perairan Teluk Jakarta. Makara Sains, 11 (1): 2836.

Stumn, W and J.J. Morgan. 1996. Aquatic Chemistry: Chemical Equilibria and Rates in Natural Waters. John Wiley \& Sons, New York.

Ward, T.J., R.L. Cornel dan R. B. Anderson. 1986. Distribution of Cadmiun Lead, and Zinc Amongst the Marine Sediment, Seagrass, and Fauna, and the Selection of Sentinel Accumulation, Near a Lead Smeller in South Australia. Aust J. Mar, Freshw. Res. 37. 567-585 